THE INTERNATIONAL

REVIEW OF RESEARCH IN

OPEN AND DISTANCE LEARNING

\title{
Who am I and What Keeps Me Going? Profiling the Distance Learning Student in Higher Education
}

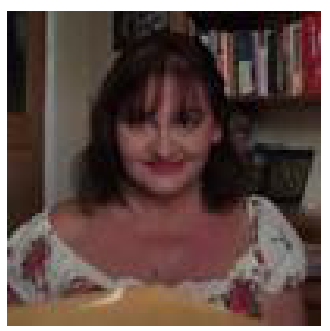

Jacqueline Baxter

The Open University, UK

\section{Abstract}

Student retention and progression has exercised the higher education (HE) sector for some time now, and there has been much research into the reasons why students drop out of higher education courses (Allen, 2006; Buglear, 2009). More recently the Higher Education Academy Grants Programme Briefing (HEFCE, 2010) outlined a number of areas that emergent project data revealed as being important to both the retention and progression of students, including areas outlined by a number of researchers as being essential to student success: expectations, support, feedback, and involvement. But there has been less research, particularly within the distance learning sector, into factors that encourage students to stay (O'Brien, 2002). This small scale qualitative project using feminist qualitative research methods and based in the Open University, UK builds upon an intensive institutional research project analyzing what type of interventions make a positive difference to student progression and success. The research revealed insights into factors linked to the expectations, identities, and support of students which proved influential in terms of their resilience and motivation to remain on course.

Keywords: Student retention; student progression; distance universities; online identity; forum moderation; online teaching; online support; student identity 


\section{Background}

Student retention and progression has exercised the higher education sector for some time now and there has been much research into the reasons why student drop out of courses ${ }^{1}$ (Fitzgibbon, 2006; Johnson, et al., 2004; Simpson, 2002; Tinto, 2009). More recently the Higher Education Academy Retention Grants Programme Briefing (HEFCE, 2010) outlined a number of areas that emergent project data revealed to be useful in adding to both retention and progression and include areas highlighted by a number of researchers as being essential to student success: expectations, support, feedback, and involvement (Schofield et al., 2010; Tinto, 2009; Yorke, 1999, 2004). The Open University, like many organisations, is rationalizing its provision in order to create an optimum student experience for the parttime distance learner; as part of this, it is changing its emphasis from a modular ${ }^{2}$ based approach (although this will still be available) to one with an emphasis on qualification pathways, moving the learner from a level one qualification through to full degree or diploma. Internationally many campus-based UK and international HE institutions are broadening their online offerings in order to provide more flexible and cost-effective ways in which students may engage with higher education. Research into what motivates distance learners and what encourages them to move from a level one to level three at undergraduate level has relevance for campus-based universities as well as those which have been engaging with online provision for some time (Stryker \& Serpe, 1994).

Work done by the UK Higher Education Academy Retention Grants Briefing Programme, (HEA 2010) outlined a number of areas which analysis revealed to contribute most to student retention and progression. These include

1. building relationships to ease student transition to university and enhance the sense of belonging;

2. use of social networking tools such as Facebook to help social and academic integration;

3. forming early strong interpersonal relationships between staff, students and their peers;

4. working closely with students to identify how they can support each other to prosper and succeed at university;

5. reducing factors that make students doubt;

6. increasing factors that make students want to stay;

7. building communications between families and students.

Research into student retention and progression has intensified over the last 40 years. The character and nature of the research has evolved within this time, and recent reviews of the

1 Courses used to denote an undergraduate qualification

2 A module is an element of study contributing either 60 or 30 credits towards an undergraduate qualification. 
literature in this area revealed key areas for action from both an institutional and sectorwide perspective (Fitzgibbon, 2006; Glogowska et al., 2007; Simpson, 2000; Tinto, 2000). Cross-sector literature in the area has identified not only future individual areas for research, but also a number of factors to be taken into consideration within any institution which hopes to make effective and quantifiable progress in the area of progression. A key challenge for institutions has been identified as the need for any progression programme to achieve centrality within that organisation, a particularly difficult area if this is not already a measure related to performance (Tinto, 1993, 2007). This has meant that for many institutions, while effective programmes to promote progression have been identified and to some extent implemented, the final outcome has had perceptibly less impact than it potentially may have done.

With 200,000 students, 7,000 associate lecturers, and some $65 \%$ of modules being offered online, The Open University has a wealth of experience and research on student retention upon which to draw. However recent figures reveal that a substantial number of students enrolling on level one modules fail to register on another module within a 12-month period. This reflects findings by other researchers within the field of distance education (Herbert, 2006; O'Brien, 2002), who note that distance courses have significantly higher dropout rates than those within campus-based universities (Moore et al., 2003). Frydenberg identifies three areas in which recent research into distance education has concentrated: individual characteristics, institutional support systems, and quality of interaction between representatives of the institution and the students (Frydenberg 2007), highlighting the latter as being key to student resilience and reflecting research also done by Simpson and Yorke (Simpson, 2000; Yorke, 1999). But other research in the field has noted that the interaction between the three areas above is more significant in terms of student identity and it is by investigating the interaction between the three elements which is most likely to yield a more holistic view of what is engendered in creation of a salient student identity: which motivational factors convince students to remain (Baxter et al., 2010; Herbert, 2006; Burke \& Reitzes, 1991; Scanlon et al., 2007). Kanter (1968) articulates these three areas as three forms of commitment: instrumental commitment or material benefits of belonging to a community, affective commitment or the positive feelings of engaging with others in the community, and moral commitment or the evaluative orientations that provide individuals with a sense of self-worth. Burke and Reizes take this further by suggesting that the meld of the three areas identified by Frydenberg combined with the forms of commitment identified by Kanter produce an identity which is "not necessarily tied to a line of activity, but tied to maintaining reflected appraisals congruent with their identity standards" (Burke \& Reitzes, 1991, p. 250), concluding that it is the level of commitment to the particular identity that indicates the degree to which levels of persistence and resilience will feature in the pursuit of a particular path.

This link between student motivation and resilience has been linked to student identity in a number of studies (Burke et al., 1981; Janks, 1999; Burke \& Reitzes, 1991; Dutton, et al., 1994; Foote, 1951; Scanlon et al., 2007) and is seen as being intrinsically linked to feelings of effectiveness, acting as a key element in the retention and motivation of the individual 
and linking strongly to performance and job satisfaction (Hotho, 2008; McAdams, 1997). Studies in professional and working identities identify that strong working identities are key to individuals' self-salience: the feeling that they are following the right path, enabling them to develop greater levels of professional resilience particularly during periods of difficulty (Baxter, 2010a, 2011; Reeve, 1992). Although student identities are not professional identities, they are working identities developed by the student to make sense of the environments within which they find themselves and subject to institutional discourses, biographical elements, and underlying personal belief systems (Joseph, 2002). They are also subject to hegemonic influences viewed from a critical realist perspective and which indicate the need for the researcher to "move beyond regularities, experiences and events and to study the underlying causal structures that provide ontological depth to identities" (Joseph, 2002; Bhaskar, 1989). To a certain extent, they are learned identities formed from a mix of personal biographies and interactions with communities within their personal and student lives (Lave et al., 1991b; Wenger, 1998), to be viewed as part of a trajectory of intersecting identities that revolve around culture, assumptions, socioeconomic background, gender, and language (Singh et al., 2006). In part they are modeled on others, yet are also uniquely individual (Edwards, 1996; Burke \& Reitzes, 1991). Just as professional identities link to motivation and emotion and feelings of doing a good job, a strong and salient student identity links to the extent to which students are retained and progress within higher education.

The diagram below, adapted from work investigating professional identities (Baxter, 2010a; Baxter, 2011a), outlines a framework for analysis of student identities. For the purposes of this study it was used alongside an institutional framework, the student journey (Figure 2), in order to identify key motivational factors, factors which may begin by influencing the student to choose the distance route rather than a traditional campus-based course through to those which influenced their successful progression between the three levels of their undergraduate degree.

Much research carried out within the higher education sector, based within both distance learning and campus-based institutions, indicates that student retention and progression is based upon a complex mix of institutional, personal, and biographical factors. But at what point in the student journey are some factors more influential than others at influencing whether a student stays or drops out (Johnson, et al., 2004; Gardner, 2000; Jones, 2008; Yorke, 1999)? The student journey conceived within The Open University is used to track student progress at various stages within a student's career. In this study it has been used to pinpoint motivational factors influencing student progression at various stages during the student's engagement with the university. Student identities are considered in this paper to meld and interlink with personal identities, forming a trajectory in which they both complement and contrast one another, as Muir and Wetherell articulate:

In social science research, a distinction is sometimes made between the study of personal and social identities. In truth, this is a rather arbitrary distinction: identity is always both about ourselves and about how we are positioned in relation to the world. (2010, p. 4) 


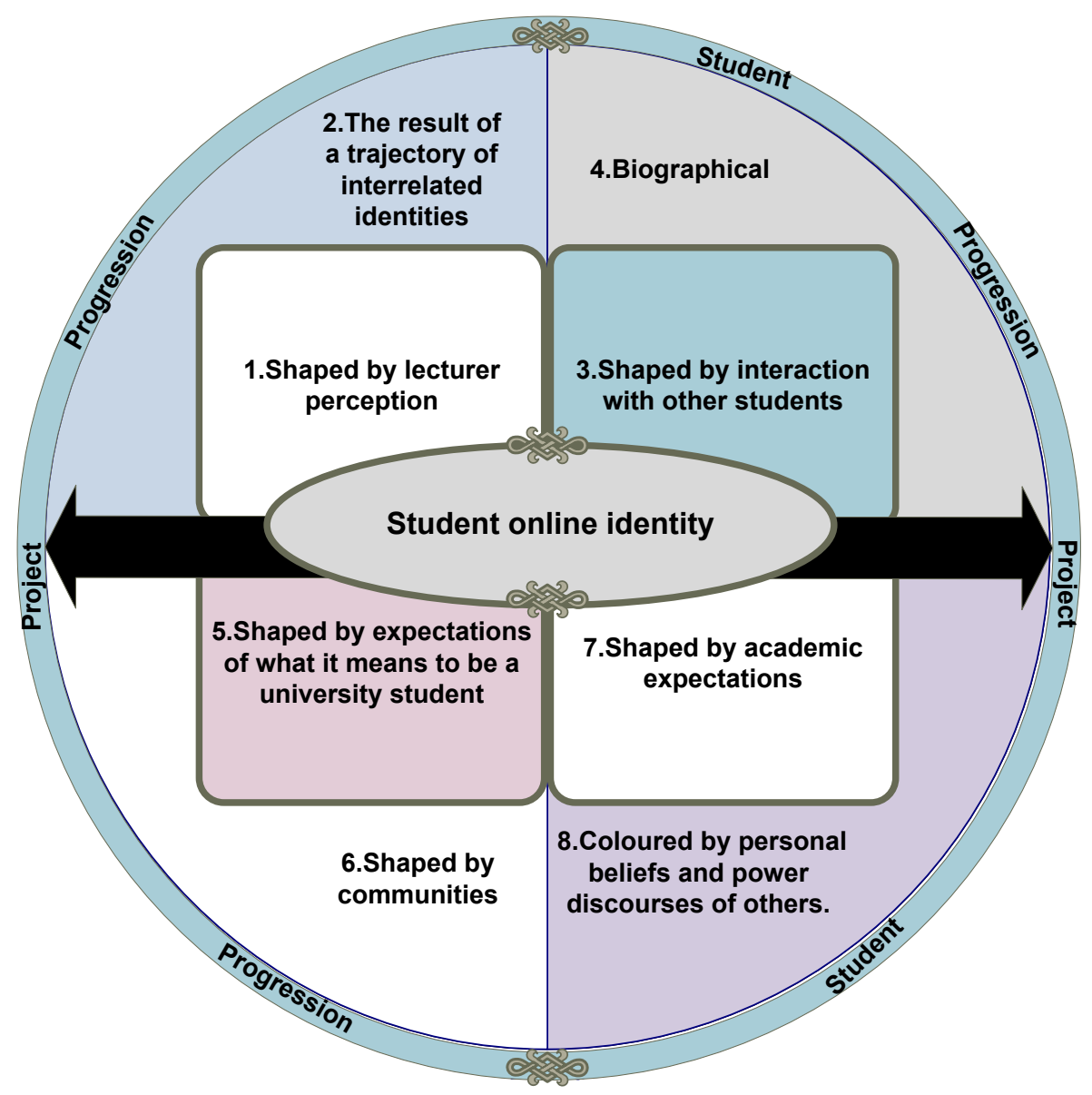

Figure 1. Factors shaping student identities adapted from Factors Shaping Online Identities (Baxter 2011a).

The factors contributing to motivation to progress were analysed according to elements comprising student identities, outlined in the diagram above. These were then mapped to the student journey.

Figure 1 offers a framework for student identity analysis and is based upon the framework for identity analysis in earlier work (Baxter, 2004); it also draws upon an extensive literature review into professional identities (Baxter 2011) and online identities in which student identities are seen to be composed of

1. lecturer perceptions;

2. the result of a trajectory of interrelated activities (Beijaard, 2004; Burke, et al., 1981);

3. interaction with others;

4. biographical elements (McAdams, 2006); 
5. expectations of what it means to be a university student;

6. communities (Wenger, 1998);

7. academic expectations (including expectations of the organization) (Jones, 2008; Schofield, et al., 2010; Simpson, 2002); and are

8. coloured by personal beliefs emanating from cultural assumptions, childhood beliefs, language, and socioeconomic background.

Within this study the framework was used to analyse the transcripts and provide insights into student motivation and progression. This is discussed more fully in the following section.

\section{Methodology}

The literature review pursued three lines of inquiry: literature on online retention, literature on retention in conventional higher education institutions, and literature on identity formation. It built on previous work on identity analysis, professional working identities, and student retention and progression (Baxter, 2011(a); Baxter, et al., 2010; Baxter, 2004). In terms of student retention the literature focused only on those studies which focused on affective, cognitive, and situative factors affecting retention and progression as these factors were outlined in previous work as important in the consideration of student identity.

For the reasons outlined above, the research follows a case study format (Yin, 1993), based in the Open University, UK. A series of 16 qualitative interviews were carried out, each lasting between 60 and 75 minutes. The interviews were carried out face to face in the homes of the respondents in order to create an environment in which participants felt comfortable and at ease speaking to the researcher (Elliot, 2005; Gorelick, 1991). Students were self-selecting and drawn from the sample ranges featured in Figure 1. The sample was approved by The University Student Research Panel and the categories chosen emanated from previous research in this area (Ashby, 2004; Baxter, et al., 2010; Johnson, et al., 2004; Jones, 2008; Leadiwood et al., 2003). Students were self-selecting and the study did not discriminate on grounds of gender. The research methodology used was based upon previous work into identity analysis and online working (Burke, et al., 1981), in which a feminist, postmodern phenomenological approach into identity analysis was taken (Langridge, 2007). The phenomenological approach has been used across the public sector to investigate the ways in which professional identities change and evolve according to the circumstances in which they are operating (Baldwin, 2008; Baxter, 2011b; Burke, et al., 1981) and has been found to be particularly useful in uncovering underlying beliefs which, in turn, underlie actions and behaviors. It is also employed by feminist researchers, placing the individual at the heart of their story; their identity is that reflected in their articulation of their own story (Josselson, 1987, 2007; Maclure, 1993). The data were analysed according to the framework in Figure 1 (discussed earlier). The self-selecting nature of the students may have given rise to a sample in which only those with very positive feelings towards the university were interviewed. The 
study acknowledges that this may have unduly positively influenced their feelings towards institutional interventions aiding their resilience and motivation. However as the aim of the study was to provide insights into factors aiding progression, this was not thought to unduly affect the overall aims of the research. The study also encountered proportionally far more female respondents than males (in the proportion 60\% to 40\%) and the reader should consider the results in light of this gender bias. It also raises the question of whether future research should focus on the differences between male and female responses in light of the research questions in this study as some studies have begun to reveal interesting differences in this area (Fozdar \& Kumar, 2007; Motiwalla \& Tello, 2001).

\begin{tabular}{|l|l|c|}
\hline Group & Description & Numbers \\
\hline A & $\begin{array}{l}\text { Students beginning study post } \\
\text { 2004 and completing a qualifi- } \\
\text { cation (without credit transfer) } \\
\text { (aged 18-25) }\end{array}$ & 2 \\
\hline B & $\begin{array}{l}\text { Students beginning their study } \\
\text { post 2004 and completing a } \\
\text { qualification without credit } \\
\text { transfer (aged 25+) }\end{array}$ & 2 \\
\hline C & $\begin{array}{l}\text { Students beginning their study } \\
\text { post 2004 and taking more than } \\
\text { 12 months out before completing } \\
\text { their qualification }\end{array}$ & 3 \\
\hline D & $\begin{array}{l}\text { Students whose study goal has } \\
\text { changed, from doing a single } \\
\text { module to getting a qualification } \\
\text { since November 2011. }\end{array}$ & 3 \\
\hline F & $\begin{array}{l}\text { Students from a large level 2 } \\
\text { course who have progressed } \\
\text { from level one to level 3. }\end{array}$ & $\begin{array}{l}\text { Students from 2 widening par- } \\
\text { ticipation initiatives. }\end{array}$ \\
\hline
\end{tabular}

Figure 2. Sample.

The sample, illustrated in Figure 2, was identified on the basis of the research carried out over the previous year, within which these groups of students were identified as having the potential to offer the most powerful insights into ways in which they had felt motivated to progress (Baxter, et al., 2010). The research formed part of an internal report for a university project on student progression in which statistical information combined with qualitative data gained from interviews with staff from regions, nations, and central academic 
units was used in order to identify factors affecting student progression. Group A students were chosen due to the fact that the university is attracting a much younger student population than at other times in its history (Maclean, 2004). These students are of particular interest to the project. Group B students still represent the university's largest population distribution, and it was hoped that insights gained by speaking to these students would be helpful in identifying motivational factors within those looking to change career or direction due to unemployment or other factors. Group D students have moved from initially only registering to do a single module (very common within the Open University) to registering on a full qualification; the reasons why this should be so were of great interest to the project. Group E students were identified due to this being the area that is most problematic: the progression from level one to level two. This has also been identified within sector research as being a period in which student drop-out rates are high. Finally, group F students were taken from the Centre for Widening Participation in order to find out how their experiences and motivations compared to other students within the study.

Before the main phase of the study, an initial pilot study was carried out in order to refine questions and ensure that students were comfortable with such in-depth interviews (Brabeck et al., 2009; Holstein et al., 1995; Macfarlane, 2006). The questions were informed by previous research into progression within the Open University and the wider sector (Jones, 2008; Trowler, 2010; Yorke, 1999). Participants were also issued with a description and purpose of the research and an ethics statement, informing them of their right to withdraw at any time. The research design and ethics protocols were approved by the University's Student Research Panel.

The research aimed to find out what factors influence positive trends in progression and to gain insight into the differing journeys of successful students. The interviews were structured around the Open University Student Journey (illustrated below). This is a framework used by the university which tracks students as they progress through various stages of engagement with the university. The first element (o) considers how their previous study experience may influence their decision to study. Moving on from there the seven further stages of the journey take the student from awareness and consideration of study options available to the final stage of completing their qualification. The journey can be considered as part of a cycle leading students from foundation levels of study through to postgraduate level.

\begin{tabular}{|l|l|l|l|}
\hline $\begin{array}{l}\text { (o)Previous study expe- } \\
\text { rience }\end{array}$ & 1.Awareness/exploration & 2.Consideration & 3.Decision \\
\hline $\begin{array}{l}\text { 4.Orientation /prepara- } \\
\text { tion }\end{array}$ & 5. Study & 6.Transition & 7.Completion \\
\hline
\end{tabular}

(Diagram adapted from The Student Journey)

The research questions were as follows:

1. In what ways have student expectations influenced student progression so far? 
2. Which factors have had the most influence on student motivation to succeed?

3. Which university initiatives have had the most positive influence on student motivation to succeed?

4. Have students experienced any drawbacks to progression between modules and if so how did students overcome them?

In order to map comments against Figure 1, quotes are numbered with the corresponding element. In cases where quotes indicate the presence of more than one student identity element, they are illustrated with the corresponding numbers. For example the quote below is indicative of expectations of what it means to be distance university student (5) whilst also indicating that academic expectations were shaping this student's perception of self (7). The quote is marked numbers 5 and 7 which indicate the corresponding identity element illustrated in Figure 1.

I thought I'd be on my own, then I realised that for some assignments I would actually be working with other students, sort of like in a group. That was so different to what I thought this would be. (student group B) $(5,7)$

\section{What Makes Students Progress}

\section{In What Ways have Students' Expectations Influenced Student Progression So Far?}

Prior to, or at the start of, Open University study, the data suggest that students have a limited understanding and limited expectations of how they will experience distance learning. They know that materials will be sent to them and that they will study them from home. But many other aspects of what the Open University provides come as something of a surprise.

I thought I'd be on my own, then I realised that for some assignments I would actually be working with other students, sort of like in a group. That was so different to what I thought this would be. (student group B) $(5,7)$

In most cases the increased engagement with others proved a pleasant surprise, but some students revealed their inhibitions when communicating in this way:

I was prepared for online work but I find it difficult to like have a conversation with people online, especially when you can't see their faces. (student group F) $(3,6)$

Insights into how this went on to affect their identity and progression reflected insecurities 
at being able to portray their identities online.

I find that some people talk as if they know it all, on the forum, that puts me off sometimes, and I thought, (when I first started), am I going to be able to get on with this? (student group D) $(8,4,3)$

The impact of the tutor was very influential at this point in terms of convincing the student that it was worth investing time and energy into learning these new ways of working: becoming part of an academic community (Wenger, 1998).

Realistic student expectations that study will require time and that it will be necessary to reorder part of their lives in order to accommodate this were found to help a great deal during the early part of their study. After that, those who approached the work strategically appeared to gain confidence in their own abilities to cope with the workload.

In the times when I was busy what I used to do was to concentrate only on the assignments and do any extra bits after I had done the work which was going to be marked. Doing things this way, I felt I was getting ahead, I felt more in control. (student group D) $(4,5)$

A clear sense of the difference between level one and level two study and realistic expectations on increased workload and autonomy proved to be important in enhancing feelings of self-efficacy and coping in the transition between levels one and two.

I could see what was available but after chatting with $\mathrm{xxx}$ (the tutor) we decided that I would be much better going for this module, she reminded me of what I'd done best in during my last module and that really helped. (student group E) $(1,5)$

Expectations and beliefs about work and study roles have been found to be important in the retention of students and professionals. Initial expectations which are not well managed can lead to a sense of let-down and erosion of confidence and feelings of agency, which if not addressed lead rapidly to attrition (Duemer et al., 2002).

The insights within this section revealed elements of student identities which focused particularly upon initial expectations around student perceptions of distance study and the ways in which they felt that they would be able to cope with this mode of study. This related particularly to group work and the ways in which they were expected to engage with other students. Responses indicated that tutor intervention at key times during the student journey, particularly just prior to making the transition between levels one and two, were key to their progression. This was particularly true when tutors were able to address metacognitive elements of student learning, moving the students forward in their choice of module 
using knowledge of their past performance, strengths, and weaknesses, able to challenge preconceptions and issues with confidence and student identity, and able to draw upon established counseling methods (Heron, 1999).

\section{Factors Influencing Motivation}

The most influential factors appeared at all stages of the student journey and linked with all three areas mentioned earlier in Frydenberg's analysis (2007). The success of these students appeared as a combination of intrinsic determination to succeed, ability to create a home environment which supports study (as mentioned earlier), along with university interventions, particularly when carried out by regional support staff or tutors. Certain characteristics appeared to be influential in creation of robust student identities. In some cases these included positive past learning experiences which created a 'can do' feeling in relation to academic work. However this was not necessarily linked to outstanding academic results; in some cases students may only have scraped through past modules. The feelings of salience, a combination of confidence and agency, seemed to emanate from the differing ways in which their successes were viewed by fellow students, family, and tutors. They also understood clearly that however much help the Open University gave them, in the end they alone were responsible for whether they succeeded or not. This keys into literature that highlights the need for individuals to feel agentive in their progress in order to remain motivated and committed to their particular pathways (Baxter, 2011; Reynolds, 2007; Simpson, 2000; Tinto, 2009)

Study structures and the ways in which students ordered their lives around the need to study linked to both personal characteristics and strategies learned from interaction with other students and feelings of integration with student communities through online forums or other social networking applications outside of university control. They made time to study so that they rarely fell behind, ensuring that both friends and family were aware that study needed to come first. As such, study has become an integral part of their personal story and history, part of the way in which they define themselves (Giddens, 1991; Goodley, 2004). In terms of their identity there was evidence that study was in some cases going some way to changing their belief systems, engaging with several of the factors influencing identity in Figure 1 (and noted alongside the quotes which follow).

Increased confidence appeared in students both through success in passing modules, but also through meeting challenges such as taking exams for the first time after many years or writing essays in spite of dyslexia. This was particularly true in cases in which students experienced the type of support which may not have been experienced previously:

I did start another course at another university, but I found that with my writing issues, I just wasn't getting the help I needed from staff, so I registered here and found it was a whole different ballgame (student group A) $(4,7,5$, 6)

Positive feelings of independence and self-reliance flowing from successful distance learn- 
ing study engendered a sense of resilience, a factor noted within sector research as being key to successful study and attainment of new student identity (Leadiwood, et al., 2003; Trowler, 2010; Yorke, 2004; Yorke et al., 2008)

Academic achievement also featured greatly in the responses: There was a notable pride within some students with regard to their ability to study at degree level, particularly if they had come from backgrounds in which they may have been the only person amongst their peer group and family to undertake university study. This proved a powerful motivator in the building of an aspirational identity:

When I first started to do this they (parents and friends), said oh this isn't you is it Mary? You aren't a university type are you? And I though well, I am doing this course aren't I? (student group D) $(2,4,6,8)$

These enhanced feelings of self-salience and efficacy, of study having permeated the identity at a deep integrative level and transformed notions of previous identities, forming a type of escape into a new persona, feature prominently in the literature on working identities (McAdams, 2006; Singh, et al., 2006). As study becomes increasingly integrated into the individual's identity, it becomes less likely that a student will give this up, or risk losing a valuable part of themselves. The point at which the new identity is integrated with existing identities has been called 'the point of metanoia' (Alsup, 2006). Lave and Wenger et al. (1991a) see it as the point at which the individual is convinced that substantial investment in the new persona will be beneficial to the individual. In the literature on higher education this is reflected in the emphasis on effective induction programmes (Leadiwood, et al., 2003; Lowe et al., 2003) as well as a focus on the ways in which students may struggle as they move between levels: not purely from an academic point of view, but also as their identity as an autonomous learner develops and they leave behind the high levels of support that they encountered in year one.

For some, improved performance at work either through putting their knowledge into practice or capacity to take on greater responsibilities acted as a powerful motivator again due to the fact that the study permeated at a deep level in terms of their identities, enhancing their personal as well as professional confidence and enabling them to feel a greater degree of agency and control within their lives.

I thought it would be a good thing to do, then I realised that I could try it out at work and suddenly people were treating me differently. (student group D) $(2,4,6)$

The positive impact of continuing professional development on the professional identity of individuals has been widely recognised as being key to feelings of professional motivation, enhancing the sense of professional purpose and engendering greater levels of flexibility and creativity in the workplace, particularly in situations in which differing priorities in multiagency working may be eroding feelings of professionalism (Atkinson et al., 2005; 
Baxter, 2011; Reynolds, 2007). The role of study has also been found to be important in increasing individuals' capacity to cope with organisational change (Anning, 2006; Daniels et al., 2007; Reeve, 1992), a constant feature of many organisations, particularly during times of austerity. This too was reflected by students:

I felt that some of the things I was learning helped me to see the bigger picture at work; I didn't get so bogged down. (student group D)(6)

This part of the discussion has highlighted the importance of student resilience in the formation of student identities. It has also drawn attention to the fragile nature of such resilience within the period during which the identities are being formed, as well as indicating the incremental nature of resilience within study. Although this phenomenon has appeared within several other studies into student retention (most commonly associated with student success), this study indicates a need for further research in this area in terms of a much wider scale study into the formation of student identity and the concomitant effect upon study resilience.

\section{What University Initiatives Have Had the Most Positive Influ- ence on Student Motivation to Succeed?}

Students outlined a number of university-led factors which had been important in making them continue. Feelings of value for money were highlighted in terms of both quality of materials provided and the levels of support provided by tutors. Some of the students, particularly those in the younger age groups, felt that it was very important to be receiving value for money. Tutors were considered to be axiomatic to the learning experience and perceptions of value for money at all points within the student journey, providing extrinsic motivation, support through difficult personal and academic periods, models and mentoring upon which to base their practices.

She always responded quickly and she knew how to point me in the right direction, she knew where to find everything (student group B) (1)

But solutions to practical and academic issues were paralleled by tutor ability to respond to more affective issues regarding confidence, personal problems, and learning difficulties:

There were problems, at home but the tutor was able to give me some good advice on how to still carry on studying (student group A) $(1,4,5)$

This affective intervention was seen as particularly important during the transition stage; although some of the students indicated that they had found central support staff very helpful, those that had experienced affective support from tutors appeared to have benefitted greatly when it came to moving from level one to level two.

It was difficult to see where to go next, even though there 
were lots of options I didn't know would be best for me until I talked to my tutor. (student group F) $(1,4)$

Tutors that carried out this activity were able to confront student beliefs that were impeding progression and remind students of how far they had come, appealing to them from a metacognitive as well as an affective dimension. This duality of dimensional approach seemed to have a more integrating effect on students, making them feel a part of both the institution and perhaps more importantly a valued member of the academic community, albeit it at a relatively peripheral level. In terms of Lave and Wenger's community of practice theory, it would tend to suggest that the tutor is more instrumental than the institution at creating a sense of integration and strengthening salience and feelings of agency (Lave, et al., 1991)

In terms of social interaction students expressed varying expectations. Most of the respondents stated that their expectations of social interaction were fairly low.

Not something I've thought about because it's distance learning. You're not going to a place; you're doing it from home really. I don't have expectations of the social side. I got the concepts of it being distance learning, being on the internet ... (student group B) $(5,8)$

For some people these expectations changed once they established themselves as students; this was particularly prevalent in group D, the group whose study goal had changed from doing a single module to aiming for a full qualification. In part, this seemed to be due to the glimpses of social life viewed through the lens of online forums, the feeling that others were interacting and having a good time.

I regret not making friends early on. Later on I did go to tutorials and made friends I am still in contact with. It was a big mistake not doing that in the first place. Once you made the connections with the people you did the tutorials with, you could monitor each other's progress and how you did. (student group D) $(3,5,7)$

Integration and contact with other students was perceived to be one of the key motivating factors in terms of student progression particularly in groups A, F, and B but concomitantly appeared as one of the factors that led to student attrition. This is discussed in the section which follows.

Although this section concentrates upon ways in which the institution effects a positive impact on student motivation to succeed, it also draws attention to a lack of knowledge around the distance learning experience, particularly in terms of the social realities of distance study. The distance learning student has access to many more social networking opportunities than in the past, and increasing familiarity with applications such as Facebook may concomitantly increase students confidence in online social engagement and the formation 
of online student identities (see Baxter 2011a for further discussion). The section which follows discusses some of the issues arising from online student social and learning interactions and their impact upon student identities.

\section{Factors Impeding Progress}

Online forums are key to university-led online interaction. In many modules they increasingly play a key part in online assessment strategies, requiring students to engage with one another in order to complete shared tasks. But forums emerged within this research as being one of the main reasons that students felt that their progress had been impeded. They also appeared to contribute to loss of confidence. Some respondents avoided them altogether or used them less than they could have, admitting to feeling intimidated and confused by postings and struggling with the practical issues of their use. Some were unprepared by removal of what moderators termed 'inappropriate postings'.

There was a discussion on the forum but it was all taken away straightaway.' (student group A) $(1,5,8)$

Students felt these issues of belonging, identity, and community were hard for the university to address but their suggestions focused on strengthening the physical bonds/contact of students through activities such as open days, visits to the regional offices or the campus at Milton Keynes. They were also keen to link up with fellow students although not necessarily by use of university social networking tools which were sometimes perceived to be problematic (discussed later in this paper). This seemed to be more of a focus for students in the younger groups:

I like to talk to other students but we've formed our own sort of group, chatting on MSN and even meeting up sometimes ...that works well (student group A) $(3,6)$

As mentioned earlier, there are tensions between initial student expectations of social interaction and the ways that they feel about this once engaged in study. Although several students admit that one of the reasons for registering with a distance learning provider was due to the fact that no physical presence would be required during study, once they began their studies some students stated how much they had gained, both in terms of motivation and also feelings of developing a student identity (being a student), by meeting with others either online or face to face. However, online interactions did present some issues for students, issues that were, at times, overcome by the intervention of an efficient moderator:

The tutors have been very good. On the forums they see somebody is beginning to flag and come in with some gentle words or you can see they have and a private email with them to say don't worry about this and they are very supportive. (student group D) $(1,5)$ 
Positive motivational factors were also described as impeding motivation at times when students had struggled. The view of the tutor varied quite substantially from being seen as purely a 'facilitator' of learning to being viewed as a mentor and role model as an active member of an occupational group which the student aspired to join. Where this was so, it seemed that the tutor had greater power in terms of their ability to override issues with curriculum, transition, and other extrinsic factors inhibiting progress. This supports evidence in the field which sees the role of the HE tutor as mentor, model, and teacher (Armitage, 1999; Clough, 2002; Cosh, 1998)

In terms of student identity, the quotes reveal that online interactions do have a substantial impact on student identities and that these are shaped by communications with both other students and tutors. The study indicates that there are some issues with the ways in which students articulate online identities that may impede motivation (or enhance it) depending upon the extent to which they are successful at this form of communication. Alternatively this may also depend upon the skill of the online moderator at developing and encouraging student contributions (see Baxter 2011 for further discussion).

\section{Conclusion}

Although small scale, the study revealed that whilst salient student identities are formed from a complex mixture of personal, social, and academic factors, there were key points at which timely interventions, particularly by tutors, could make a substantial difference to student progression. This was particularly so at transition points between levels one and two and also during the induction period. Although many past studies of distance learning indicate that it attracts the type of student who is not particularly interested in socialising and interacting with others, this was certainly not the case in this study. A particularly interesting point that emerged during the research was the mismatch between initial expectations of social interaction and the ways in which these expectations changed and evolved during the study period. Again this was particularly marked in interviews with students from the younger age groups (under 25) but also appeared in all of the groups. This suggests that not only are student perceptions of distance learning changing, but that online interactions outside of the university may well be responsible for the feeling that social interaction plays a far greater part in fully online learning than it did in more blended modes. The study supported work done by HEFCE (2010) and the Higher Education Academy (2010, 2011), but also suggests that the expectations of students who study at a distance are changing partly due to the ability of some of their colleagues to initiate and sustain very successful online interactions and relationships with other students. For some students this is a motivating factor, particularly if interventions from both tutors and support staff are able to address lack of confidence in this area. If not addressed, this study suggests that the feelings of exclusion precipitated by lack of ability to successfully form online friendships may be equally, if not more, powerful reasons than academic issues in terms of why distance learning students fail to progress. It also suggests that this element is key to the formation and sustenance of the type of salient student identity which is robust and resilient enough to ensure that they progress from an initial module through to a full degree. 
The study also indicated the ways in which student identity influences student resilience and capacity to progress from one level of study to another, confirming it to be a key factor to be addressed in future studies of retention and progression within the realm of distance learning in higher education.

\section{Acknowledgement}

The author would like to acknowledge the help of J. Leach who assisted with the fieldwork for this study. 


\section{References}

Allen, T. H. (2006). Is the rush to provide on-line instruction setting our students up for failure? Communication Education, 55(1), 122-126.

Alsup, J. (2006). Teacher identity discourses negotiating personal and professional spaces. New Jersey: Lawrence Erlbaum Associates Ltd.

Anning, A. (2006). Developing multi-professional teamwork for integrated children's services: Research, policy and practice. Open Univ Pr.

Armitage, A., Briant, R., Hammersley, M., Hayes, D., \& Lawes, S. (1999). Teaching and training in post compulsory education. Buckingham: Open University Press.

Ashby, A. (2004). Monitoring student retention in the Open University: Definition, measurement, interpretation and action. Open Learning, 19(4), 65-77.

Atkinson, M., Doherty, P., \& Kinder, K. (2005). Multi-agency working. Journal of Early Childhood Research, 3(1), 7.

Baldwin, L. (2008). The discourse of professional identity in child and adolescent mental health services. University of Nottingham, Nottingham.

Baxter, J. (2011). Public sector professional identities: Etiolation or evolution; a review of the literature. Milton Keynes The Open University UK. Retrieved from http://oro. open.ac.uk/29793/

Baxter, J. (2011a). An investigation into the role of professional learning on the online teaching identities of higher education lecturers. The Open University UK, Milton Keynes. Retrieved from http://oro.open.ac.uk/33928/

Baxter, J., \& Martyn, R. (2010). Student progression: Effective interventions and areas for development. The Open University UK.

Baxter, J. (2010a). Bien dans sa Peau : An investigation into the role of professional learning on the online teaching identities of HE lecturers. Paper presented at the 21 Century Academic Identities Conference, The University of Strathclyde. Retrieved from http://oro.open.ac.uk/26313/

Baxter, J. (2004). Investigation into motivational factors behind using a second language as a means to gaining employment. Retrieved from http:/www.cilt.org.uk/research/statistics/labourmarket/

Bhaskar, R. (1989). Reclaiming reality. London: Verso. 
Beijaard, D., Meijer, P.C., \& Verloop, N. (2004). Reconsidering research on teachers' professional identity. Teaching and Teacher Education, 20, 107-128.

Brabeck, M., \& Brabeck, K. (2009). Feminist perspectives on research ethics. In The handbook of social research ethics (pp. 39-53).

Buglear, J. (2009). Logging in and dropping out: Exploring student non-completion in higher education using electronic footprint analysis. Journal of Further \& Higher Education, 33(4), 381-393.

Burke, P. J., \& Reitzes, D. C. (1991). An identity theory approach to commitment. Social Psychology Quarterly, 239-251.

Burke, P. J., \& Reitzes, D. C. (1981). The link between identity and role performance. Social Psychology Quarterly, 83-92.

Clough, P. (2002). Narratives and fictions in educational research. Buckingham: Open University Press.

Cosh, J. (1998). Peer observation in higher education - A reflective approach. Innovations in Education and Training International, 35, 171-176.

Daniels, H., Leadbetter, J., Warmington, P., Edwards, A., Martin, D., Popova, A., et al. (2007). Learning in and for multi-agency working. Oxford Review of Education, 33(4), 521-538.

Duemer, L., Fontenot, D., Gumfory, K., Kallus, M., Larsen, J. A., Schafer, S., et al. (2002). The use of online synchronous discussion groups to enhance community formation and professional identity development. The Journal of Interactive Online Learning, 1(2), 1-12.

Edwards, R. (1996). Troubled times? Personal identity, distance education and open learning. Open Learning, 11(1), 3-11.

Elliot, J. (2005). Using narrative in social research. London: Sage.

Fitzgibbon, K. a. P., J (2006). Student's early experiences and university interventions - a timeline to aid undergraduate student retention. Widening Participation and Lifelong Learning, 8(3), 1, 7-46.

Fozdar, B. I., \& Kumar, L. (2007). Mobile learning and student retention. International Review of Research in Open and Distance Learning, 8(2), 18.

Giddens, A. (1991). Modernity and self-identity. Cambridge MA: Polity Press.

Glogowska, M., Young, P., \& Lockyer, L. (2007). Should I go or should I stay?: A study of factors influencing students' decisions on early leaving. Active Learning in Higher 
Education, 8(1), 63-77.

Goodley, D., Lawthom, R., Clough, P., \& Moore, M. (2004). Life Stories, method theory and analayses in a biographical age. London: Routledge.

Gorelick, S. (1991). Contradictions of feminist methodology. Gender and Society, 5, 459477.

Harrell, I. L., \& Bower, B. L. (2011). Student characteristics that predict persistence in community college online courses. American Journal of Distance Education, 25(3), 178-191.

HEA. (2010). Retention grants programme briefing 2.

HEA (2011). Higher Education Academy what works? Student retention and success. Retrieved from http://www.heacademy.ac.uk/retention-and-success

Frydenberg, J. (2007). Persistence in university continuing education online classes. The International Review of Research in Open and Distance Learning, 8(3).

Higher Education Funding Council for England (HEFCE) (2010). Retention grants briefing programme number 3. Bristol HEFCE - Paul Hamlyn Foundation. Retrieved from http://www.hefce.ac.uk/

Herbert, M. (2006). Staying the course: A study in online student satisfaction and retention. Online Journal of Distance Learning Administration, 9(4). Retrieved from http:// fsweb.bainbridge.edu/qep/Files/TeachingRes/Staying\%20the\%20Course.pdf

Heron, J. (1999). The complete facilitator's handbook. London: Kogan Page

Holstein, J. A., \& Gubrium, J. F. (1995). The active interview. Thousand Oaks: Sage.

Hotho, S. (2008). Professional identity-product of structure, product of choice: Linking changing professional identity and changing professions. Journal of Organizational Change Management, 21(6), 721-742.

Janks, H. (1999). Critical language awareness journals and student identities. Language Awareness, 8(2), 111-122.

Johnson, G. C., \& Watson, G. (2004). 'Oh gawd, how am I going to fit into this?': Producing [mature] first-year student identity. Language \& Education: An International Journal, 18(6), 474-487.

Joseph, J. (2002). Hegemony: A realist analysis. London: Routledge.

Jones, R. (2008). Student retention and success: A synthesis of research. York: The Higher Education Academy. 
Josselson, R. (1987). Finding herself: Pathways to identity development in women. San Francisco: Jossey- Bass.

Josselson, R. (2007). Playing Pygmalion: How people create one another. New York: Jason Aronson.

Kanter, R. M. (1968). Commitment and social organization: A study of commitment mechanisms in utopian communities. American Sociological Review, 499-517.

Langridge, D. (2007). Phenomenological psychology. London: Prentice Hall.

Lave, J., \& Wenger, E. (1991). Situated learning: Legitimate peripheral participation. Cambridge: Cambridge University Press

Leadiwood, C., \& O'Connell, P. (2003). 'It's a struggle': The construction of the 'new student' in higher education. Journal of Education Policy, 18(6), 597-615.

Lowe, H., \& Cook, A. (2003). Mind the gap: Are students prepared for higher education? Journal of Further and Higher Education, 27(1), 53-76.

Macfarlane, B. (2006). Researching with integrity. London: Routledge Farmer.

Maclean, S.(2004). Students turn to OU to avoid debt. Retrieved from http://www.guardian.co.uk/education/2004/jan/12/students.accesstouniversity

Maclure, M. (1993). Some thoughts on self-talk in research contexts. British Journal of the Sociology of Education, 14(4), 373-384.

McAdams, D. P. (1997). Stories we live by; personal myths and the making of the self. Guildford: Guildford Press.

McAdams, D. P., Josselson, R., \& Lieblich, A. (2006). Identity and story; create self in narrative. Washington DC: American Psychological Association.

Mishler, E. (2000). Storylines: Craft narratives of identity. Cambridge MA: Harvard University Press.

Moore, K., Bartkovich, J., Fetzner, M., \& Ison, S. (2003). Success in cyberspace: Student retention in online courses. Journal of Applied Research in the Community College, $10(2), 12$.

Motiwalla, L., \& Tello, S. (2001). Distance learning on the Internet: An exploratory study. The Internet and Higher Education, 2(4), 253-264.

Muilenburg, L., \& Berge, Z. L. (2001). Barriers to distance education: A factor-analytic study. American Journal of Distance Education, 15(2), 7-22. 
Muir, R., \& Wetherell, M. (2010). Identity, politics and public policy. Institute for Public Policy Research. Retrieved from http://www.ippr.org/publications/55/1765/ identity-politics-and-public-policy

O’Brien, B. S. (2002). Online student retention: Can it be done? In P. Barker \& S. Rebelsky (Eds.), Proceedings of World Conference on Educational Multimedia, Hypermedia and Telecommunications (pp. 1479-1483).

Reeve, J. M. (1992). Understanding motivation and emotion. Fort Worth: Harcourt Brace Jovanovich College Publishers.

Reynolds, J. (2007). Discourses of inter-professionalism. British Journal of Social Work, $37(3), 441$.

Scanlon, L., Rowling, L., \& Weber, Z. (2007). 'You don't have like an identity...you are just lost in a crowd': Forming a student identity in the first-year transition to university. Journal of Youth Studies, 1O(2), 223-241.

Schofield, C., \& Dismore, H. (2010). Predictors of retention and achievement of higher education students within a further education context. Journal of Further \& Higher Education, 34(2), 207-221.

Simpson, O. (2000). Supporting students in open and distance learning. Open and Distance Learning Series. London Kogan Page.

Simpson, O. (2002). Supporting students in online, open and distance learning. Routledge Falmer.

Singh, V., Vinnicombe, S., \& James, K. (2006). Constructing a professional identity: How young female managers use role models. Women in Management Review, 21(1), $67-81$.

Stryker, S., \& Serpe, R. T. (1994). Identity salience and psychological centrality: Equivalent, overlapping, or complementary concepts? Social Psychology Quarterly, 16-35.

Tinto, V. (2009). How to help students stay and succeed. Chronicle of Higher Education, 55(22), A33-A33, 31-34.

Tinto, V. (2007). Research and practice of student retention: What next? College Student Retention, 8(1), 1-19.

Tinto, V. (2000). What have we learned about the impact of learning communities on students? Assessment Update, 12(2), 1.

Trowler, V. (2010). Student engagement literature review. Lancaster University. Retrieved from http://www.heacademy.ac.uk/assets/documents/studentengagement/ StudentEngagementLiteratureReview.pdf 
Wenger, E. (1998). Communities of practice: Learning meaning and identity. New York: Cambridge University Press.

White, C. (2007). Innovation and identity in distance language learning and teaching. International Journal of Innovation in Language Learning and Teaching, 1(1), 97110.

Yin, R. K. (1993). Applications of case study research. London: Sage.

Yorke, M., \& Longden, B. (2008). The first year experience of higher education in the UK. York: The Higher Education Academy

Yorke, M. (2004). Retention, persistence and success in on- campus higher education, and their enhancement in open and distance learning. Open Learning, 1(9), 19-33.

Yorke, M. (1999). Leaving early: Undergraduate non-completion in higher education. London: Falmer.

\section{Athabasca University $\mathbf{Z}$}

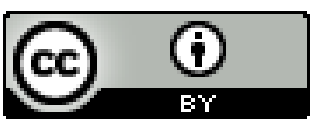

